\title{
Status, Values and Challenges in Chiropterans Conservation
}

\author{
Richa Niraula ${ }^{1}$ and Sunny Jha ${ }^{2}$ \\ Corresponding author: Richa Niraula \\ Email: richaniraula@gmail.com
}

\begin{abstract}
Chiropterans (Bats) comprise 1,001 species in total and are distributed worldwide. These have high ecological and economical value. Nepal comes under the highlighted subregion in the South Asia owing to the abundance of bats over here. Yet, very few detailed analyses have been done, and the exact status including biological habits are still not properly documented. This has made already vulnerable population more vulnerable with a continuous threat that some valuable species might get lost even before realizing. This paper provides insight to the status of bats in Nepal, the challenges present in their conservation and the ways ahead.
\end{abstract}

Key Words: Chiropterans, Ecological Value, Economical Value, Issues and Challenges.

\section{Introduction}

The order Chiroptera contains 1,001 species of bats globally, and are sub-categorized as Megachiroptera (Fruit bats) and Microchiroptera (Insectivorous bats), on the basis of their specialization in feeding habitat and morphological adaptation (Hutson et al. 2001). Among the total of 1,001 species of the bats found, about half are currently at risk (SMM 2011). These are distributed worldwide with the exceptions of the areas of the Arctic and Antartic, and isolated oceanic islands (Mickelburgh et al.1992). In the Northern Hemisphere, Palaearctic bats have been recorded as far as north as $70^{\circ} \mathrm{N}$ ( Rydell et al. 1994), while in Southern hemisphere, bats have been found south of Tierra del Euego in Chile, at a latitude of $65^{\circ} \mathrm{S}$ (Koopman 1967). In South Asia alone, 17 species are endemic out of the total 123 species found.

These come under highly overshadowed and neglected species all over the world. Lack of public awareness, enough documentation and research and lower charismatic value in comparison to other flag species have always kept bats in the lower order in the conservatory aspects. With the celebration of United Nations decade of biodiversity (2010-2020), this

${ }^{1}$ Student, Kathmandu Forestry College 
year 2011 coincides with both year of Forest and year of Bats. Even with this, bats are still mysterious and very little is known about them. This paper talks about the ecological and economic values of the bats, conservatory issues and the ways forth.

\section{Ecological and Economical value of Bats}

Fruit eating bats play an important role in the pollination and seed dispersal of many tropical plants. In the Neotropics, phyllostomoid bats act as seed dispersal agents for up to $24 \%$ of forest tree species at some sites (Humphrey and Bonaccorso, 1979). There are over 100 phyllostomoid species that are responsible for dispersing seeds of pollinating plants, many of which are commercially valuable (Dobat and Piekert-Holle, 1985). For instance, an individual Carollia, one of the most important disperser for the Piper species in Neotropics, and crucial to many pioneer plants, eats about 35 Piper or 8-10 Cecropia fruits in a typical night. It moves relatively short distances before consuming these fruits, with the result that most seeds are dispersed close to the parent plant. Each bat may eat up to 60,000 seeds a night; a colony of 400 could disperse 146 million seeds annually. Even if only $0.1 \%$ of these germinate, that represents 146,000 seedlings ( Fleming, 1988). In the neo-tropics, the bat dispersed plants, such as, Cecropia, Piper are among the first and most abundant species to invade natural and human-made clearings (Hutson et al.2001). Apart from their contribution in seed dispersal, bats also have profound role in pollination of many plant species.

Insectivorous bats are also crucial from both ecological and economical aspect. However, economical aspect has not been analysed in detail for them unlike for fruit consuming bats ( Fujita and Tuttle, 1991). Some of the insectivorous bats consume very large quantities of insects. For example, in the USA, Tadarida brasiliensis, which can roost in colonies numbering 20 million, may ingest $50-70 \%$ of its body mass per night( Kunz et al.1995) and Myotis lucifugus as much as $100 \%$ ( Kurta et al. 1989).In a study in Southeastern Ontario, Canada, little brown bats ( M.lucifugus) fed predominantly on mosquitoes, which was revealed by the mosquito remains in $85 \%$ of the total faecal samples, suggesting that this species could play an important role in the biological control of insect pests ( Fascione et al.1991). Bats also consume a variety of other insects including Lepidoptera, Coleoptera, Homoptera, Hemiptera and Trichoptera (Ross, 1967; Black, 1974; Kunz, 1974a; Whitaker and black, 1976; Anthony and Kunz, 1977; Whitaker et al.1977; Warner, 1984; Swift et al.1985; Dalton et al. 1986; Rydell, 1986; Kunz et al. 1995).

Guano, Bats' faeces also have high economic value as fertilizer. It comes in the top ten biological fertilizer in the world (Adhikari, 2008). Though it has been replaced by the chemical fertilizers in developed countries, it is still an important source of revenue in developing world (IUCN 2001).

Snakes, hawks, owls are the natural predators of bats. This mutual relation between the prey and predator makes the ecosystem run smoothly. 


\section{Abundance and Condition in Nepal}

Nepal comes under the highlighted sub-region within Asia owing to the $40.6 \%$ coverage in bats availability in South Asian region. At least, 37 species are known to live and breed in Nepal (BPP, 1995), whereas Hutson et.al (2001) reported 51, and 53 species were reported by Baral and Shah (2008) of which 39 species are in threat as per the IUCN report (IUCN, 2006). In recent years, bats, though with low charismatic factor, are slowly attracting more and more conservationists and researchers, adding new information to what we already have.

Among the 51 species found in Nepal, 4 are megachiropterans and remaining 47 belong to microchiropteran category. Among these all, only one, Myotis csorbai is endemic to Nepal. History about the bat research in Nepal has its origin from the $19^{\text {th }}$ century, yet, very least has been explored. People still consider bats as bad omen, vampire and sinister. This negative attitude has led to the merciless killings in many parts of the country, evidences of bat trade in Shaktikhor Bazaar, Chitwan( SMM 2011) also prevail. Nepal is blessed with wildlife; however, we are generally obsessed with some few flag species having high charismatic value. Because of this, small mammals like bats are generally neglected, which actually contribute more than $60 \%$ of the total wildlife in the country (SMCRF Report 2010).Bats are widespread in Nepal, their distribution being observed and studied from different districts, at different altitudes by various researchers. These small species have been found in caves, abandoned houses, mines, church and trees too. Being nocturnal in habit, their study is most often rendered difficult. Different authors have provided checklist for their abundance in Nepal, one provided by Adhikari et al. (2008) has been given below-

\begin{tabular}{|l|l|l|l|}
\hline S.N & Scientific Name & Common Name & Red List/NP List \\
\hline & Pteropodidae & & \\
\hline 1. & Rousettus leschenaulti & Leschenault's rousette & NT \\
\hline 2. & Pteropus giganteus & Indian flying fox & LC/CITES II \\
\hline 3. & Cynopterus sphinx & Greater short-nosed fruit bat & LC \\
\hline 4. & Sphaerias blanfordi & Blanford's fruit bat & NT \\
\hline & Megadermatidae & & \\
\hline 5. & Megaderma lyra & Greater false vampire bat & LC \\
\hline & Rhinolophidae & & \\
\hline 6. & Rhinolophus affinis & Intermediate horse shoe bat & LC \\
\hline 7. & R. ferrumequinum & Greater horse shoe bat & NT/ CITES III \\
\hline 8. & R. Lepidus & Blyth's horse shoe bat & NT \\
\hline 9. & R. luctus & Wooly horseshoe bat & NT \\
\hline 10. & R. macrotis & Big eared horse shoe bat & NT \\
\hline 11. & R. pearsonii & Pearson 's horse shoe bat & LC \\
\hline 12. & R. pusillus & Least horseshoe bat & LC \\
\hline
\end{tabular}




\begin{tabular}{|c|c|c|c|}
\hline 13. & R. rouxii & Rufous horse shoe bat & NT \\
\hline \multirow[t]{2}{*}{14.} & R. subbadius & Little Nepalese horseshoe bat & EN \\
\hline & Hipposideridae & & \\
\hline 15. & Hipposideros armiger & Great Himalayan leaf nosed bat & LC \\
\hline 16. & H. ciniraceous & Ashy roundleaf bat & NT \\
\hline 17. & H. fulvus & Fulvus roundleaf bat & LC \\
\hline \multirow[t]{2}{*}{18.} & H. pomona & Anderson's leaf nosed bat & NT \\
\hline & Miniopteridae & & \\
\hline 19. & Miniopterus pusillus & Small bent-winged bat & CR \\
\hline \multirow[t]{2}{*}{20.} & M. schreibersii & Schreiber's long -fingered bat & LC/ CITES III \\
\hline & Vespertilionidae & & \\
\hline 21. & Myotis blythii & Lesser mouse- eared bat & VU \\
\hline 22. & M. formosus & Hudgon's bat & NT \\
\hline 23. & M. mystacinus & Whiskered bat & VU \\
\hline 24. & M. muricola & Whiskered myotis & $\mathrm{LC}$ \\
\hline 25. & M. longipes & Kashmir cave bat & NT \\
\hline 26. & M. siligorensis & Himalayan whiskered bat & NT \\
\hline 27. & M. csorbai & & DD \\
\hline 28. & M. cecarius & Mandelii's mouse eared bat & VU \\
\hline 29. & Plecotus auritus & Brown long- eared bat & NT \\
\hline 30. & P. austriacus & Grey long-eared bat & NT \\
\hline 31. & Barbastella leucomelas & Asian (or Eastern) Barbastelle & NT \\
\hline 32. & Scotomanes ornatus & Harlequin bat & NT \\
\hline 33. & Scotophilus kuhlii & & NT \\
\hline 34. & S. heathii & Asiatic greater yellow hose bat & $\mathrm{LC}$ \\
\hline 35. & Eptesicus serotinus & Serotine & NT \\
\hline 36. & E. gobiensis & Gobi big brown bat & DD \\
\hline 37. & E. dimissus & Surat serotine & VU \\
\hline 38. & Ia io & Great evening bat & $\mathrm{CR}$ \\
\hline 39. & Pipistrellus javanicus & Javan pipestrelle & $\mathrm{LC}$ \\
\hline 40. & P. coromandra & Indian pipistrelle & $\mathrm{LC}$ \\
\hline 41. & P. trenuis & Least pipistrelle & LC \\
\hline 42. & P. affinis & Chocolate pipistrelle & SU \\
\hline 43. & P. circumdatus & Black-gilded pipistrelle & NT \\
\hline 44. & Nyctalus montanus & Mountain noctule & NT \\
\hline 45. & N. noctula & Noctule & $\mathrm{LC}$ \\
\hline
\end{tabular}




\begin{tabular}{|l|l|l|l|}
\hline 46. & Hesperoptenus tickelii & Tickell's bat & DD \\
\hline 47. & Murina cyclotis & Round-eared-tube-nosed bat & LC \\
\hline 48. & M. aurata & Little tube- nosed bat & NT \\
\hline 49. & M. leucogaster & Greater tube- nosed bat & VU \\
\hline 50. & M. huttoni & Hutton's tube-nosed bat & DD \\
\hline 51. & Kerivoula picta & Painted bat & LC \\
\hline 52. & Philetor brachypterus & Rohu's bat & VU \\
\hline & Emballonuridae & & \\
\hline 53. & Taphozous longimanus & Long-winged tomb bat & DD \\
\hline
\end{tabular}

DD- Data Deficient, VU- Vulnerable, NT- Not Threatened, LC- Least Concerned, CR- Critically Endangered, EN- Endangered, SU- Status Unknown

Source: Adhikari et al. 2008

Issues and Challenges

There are various issues and challenges in bat conservation which need to be addressed. But, the way forth is not an easy one. The issues and challenges present in the current scenario are-

1. Increasing Human population

Increasing human population implies extra demands for land, food and almost all the resources. This often, results in the degradation and destruction of certain habitat types with a concomitant effect on bat populations.

2. Habitat Destruction and Modification

Increasing population creates high pressure in land resources, especially in the forested areas. These forests support large number of bat colonies. Rapid deforestation, habitat fragmentation, change in the land use pattern, over grazing have caused destruction and modification in the bat habitats, causing decline in their population.

3. Roost Site Disturbance

Loss of trees, alterations in the roosted buildings and miming activities are worldwide threat for bat population. This threat, especially to the karst ecosystems, has increased so much that it has led to the drafting of Guidelines for cave and Karst Protection under the IUCN World Commission on Protected Areas (Watson et al.1997). Unmanaged tourism in such sites and caving have also contributed in bat declination.

4. Persecution

Bats are still considered as bad omen, evil and objects of fear in most of the societies. Combination of this thought with lack of awareness has led to the persecution of bats in many places in the world. 
5. Lack of Information

This is probably the greatest threat to bats. Out of the 1,001 species found in the worldwide, very few have been studied properly. The condition is even worse in the developing countries owing to the lack of resources and awareness.

These threats need to be carefully studied and then addressed so as to get the maximum protection. All of the above mentioned threats are the outcome of human activities in one or another way. Impact of the human interference in bats' habitat in South Asia has been explained with the help of below given pie-chart.

Ways to mitigate the prevailing threats

1. Constant monitoring and research

2. Controlling deforestation and habitat fragmentation

3. Raising public awareness

4. Establishing bat houses and clubs

5. Strong implication of laws

6. Sustainable management of caves and other bat habitats

7. Encouraging individuals and organizations to work for bats conservation

\section{Conclusion and Recommendations}

Even though the tiny chiropterans have high ecological and economical values, these have not been properly studied. There are many threats in conservation, major one being

\section{Loss in bats' habitat from human interferencein South Asia}

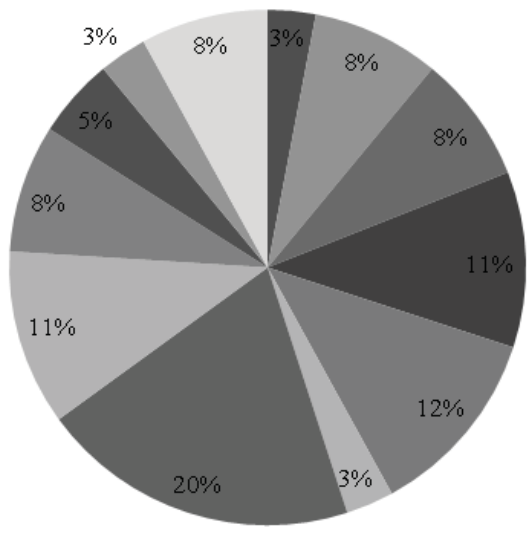

Source: C.A.M.P Summary, 2002

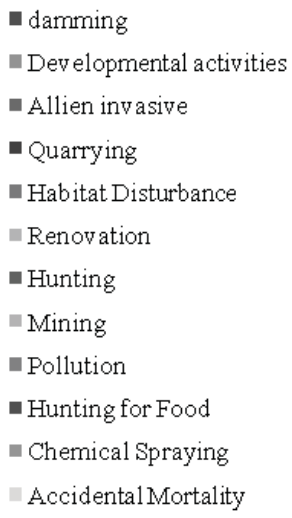


the chances of losing some species of bats before knowing about them properly. There is the immediate need of addressing the existing issues, for which awareness at local level, advanced research works and knowledge sharing could be some. More specifically, options like captive breeding, reintroduction of the species, genome preservation and constant monitoring could be applied. On this regard, this International Bat Year-2011 could be a major turning point, provided we do not consider the conservation of species based only on their charismatic factor.

\section{Reference}

Mickleburgh, S.P.,Hutson A.M. and Racey P.A.(Compiler)1992. Old world Fruit Bats: An Action Plan for their Conservation. IUCN/ SSC. Chiroptera Specialist Group. IUCN, Gland, Switzerland.

Hutson, A.M., Mickeburgh, S.P. and Racey, P.A. (Compilers) 2001. Microchiropteran Bats: Global Status, Survey and Conservation Action Plan. IUCN/SSC. Chiroptera Specialist Group. IUCN, Gland, Switzerland and Cambridge, UK, x+258 pp.

Rydell, J., Straun, K.B. and Speakman, J.R. 1994. First Record of breeding bats above the Arctic Circle: Northern bats at 68ㅇN in Norway. Journal of Zoology London, 233(2), 335-339.

Koopman, K.F. 1967. The Southernmost bats. Journal of Mammology, 48, 487-488.

Humphrey, S.R. and Bonaccorso, F.J. 1979. Population and community ecology. Pp.409-441 in: Biology of the bats of the New World family Phyllostomatidae. Part 3(eds.Baker, R.J., Jones Jr.J.K. and Carter, D.C.).Special Publications of the Texas Tech University No.16.

Dobat, K. and Piekert- Holle, T. 1985, Blüten und Fledermaüse; Bestäubung durch Fledermäuse und Flughunde. Waldemar Kramer, Frankfurt am Main.

Fleming, T.H. 1988. The short- tailed fruit bat. A study in plant-animal interaction. University of Chicago Press, Chicago and London.

Fujita, M.S. and Tuttle, M.D. 1991. Flying foxes( Chiroptera: Pteropodidae): Threatened animals of key economic importance. Conservation Biology, 5, 455-463.

Kunz, T.H., Whitaker Jr. J.O.and Wadanoli, M.D. 1995. Dietary energetics of the insectivorous Mexican free-tailed bat(Tadarida brasiliensis) during pregnancy and lactation. Oecologia (Berlin), 101, 407-415.

Kurta, A., Bell, G.P., Nagy, K.A. and Kunz, T.H. 1989. Energetics of pregnancy and lactation in freeranging little brown bats ( Myotis lucifugus). Physiological Zoology, 62, 804-818.

Fascione, N., Marceron, T. and Fenton, M.B. 1991. Evidence for mosquito consumption in $M$. lucifugus. Bat Research News, 32(1), 2-3.

Ross, A.1967. Ecological aspects of food habits of insectivorous bats. Proceedings of the Western Foundation of Vertebrate Zoology, 1, 205-263. 
Black, H.L. 1974. A north temperate bat community : Structure and prey populations. Journal of Mammalogy, 55, 138-157.

Kunz, T.H. 1974a. Feeding ecology of a temperate insectivorous bat, Myotis velifer. Ecology, 55, 693-711.

Whitaker, Jr., J.O. and Black, H.L.1976. Food habits of cave bats from Sabia, Africa. Journal of Mammalogy, 57, 56-65.

Anthony, E.L.P. and Kunz, T.H. 1977. Feeding strategies of the little brown bat, Myotis lucifugus, in Southern New Hemisphere. Ecology, 58, 755-786.

Whitaker, Jr. J.O., Maser, C. and Keller, L.E. 1977. Food habits of bats of western Oregon. Northwest Science, 51, 46-55.

Warner, R.M. 1984. Interspecific and temporal dietary variation in an Arizona bat community. Journal of Mammalogy, 66, 45-51.

Swift, S.M., Racey, P.A. and Avery, M.I. 1985. Feeding ecology of Pipistrellus pipistrellus ( Chiroptera: Vespertilionidae) during pregnancy and lactation. 2. Diet . Journal of Animal Ecology, 54, 217-225.

Dalton, V.M., Brack, Jr.V. and McTeer, P.M. 1986. Food habits of the big-eared bat, Plecotus townsendii virginianus, in Virginia. Virginia Journal of Science, 37, 248-254.

Rydell, J. 1986. Foraging and diet of the northern bat Eptesicus nilsonii in Sweden. Holoarctic Ecology, 9, 272-276.

Adhikari, H., Kafley, G. and Koirala, R. 2008. Bat Conservation in Nepal: An Educational Kit.

Watson, J., Hamilton- Smith, E., Gillieson and Kiernan, K. (eds.). 1997. Guidelines for cave and karst protection. IUCN, Gland, Switzerland and Cambridge, UK. 